\title{
СТРУКТУРА ЗАДЕРЖКИ ПОЛОВОГО СОЗРЕВАНИЯ У ДЕВОЧЕК В ЗАВИСИМОСТИ ОТ КЛИНИЧЕСКОЙ КАРТИНЫ
}

Каболова К.Л., Латышев О.Ю., Окминян Г.Ф., Киселева Е.В., Ромайкина Д.С., Касаткина Э.П., Самсонова Л.Н.

ФГБОУ ДПО «Российская медицинская академия непрерывного профессионального образования» Министерство здравоохранения Российской Федерации, Москва

ЦЕЛЬ: изучить структуру задержки полового созревания у девочек в зависимости от клинической картины.

МАТЕРИАЛЫ И МЕТОДЫ: обследована 51 девочка в возрасте 14,2士0,82 лет с задержкой полового созревания.

Критерии включения: отсутствие вторичных половых признаков в возрасте $\geq 13$ лет, или отсутствие менархе в возрасте $\geq 15$ лет, или отсутствие менархе в течение 3 лет и более от начала появления эстрогензависимых признаков полового созревания.

Критерии невключения: возраст $\geq 18$ лет, неправильное строение наружных половых органов.

В зависимости от клинической картины все пациентки разделены на три группы:

- I группа - девочки с отсутствием вторичных половых признаков в возрасте $\geq 13$ лет (B1 по шкале Таннер, средний возраст 13,6士0,7 лет).

- II группа - девочки с отсутствием прогрессирования вторичных половых признаков в возрасте

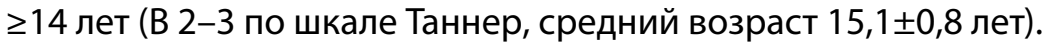

- III группа - девочки с отсутствием менархе, в возрасте $\geq 15$ лет (B 4-5 по шкале Таннер, средний возраст 15,5 $\pm 0,5$ лет).

У всех девочек оценивали стадию полового развития по шкале Таннер, антропометрические показатели, костный возраст, генитометрические показатели, содержание лютеинизирующего гормона, фолликулостимулирующего гормона, эстрадиола, пролактина, тестостерона, дегидроэпиандростерона сульфата, ингибина В, антимюллерова гормона в сыворотке крови, тест с аналогом ГнРГ ( $\mathrm{n}=24)$. Проводили цитогенетическое исследование $(\mathrm{n}=45)$, молекулярно-генетический анализ $(\mathrm{n}=7)$, МРТ головного мозга с контрастированием $(\mathrm{n}=5)$.

Для анализа данных использовалось классификационное деление на 2 группы: перманентная форма задержки полового созревания (гипогонадотропный гипогонадизм, гипергонадотропный гипогонадизм) и транзиторная форма (функциональный гипогонадизм, конституциональная задержка пубертата).

PЕЗУЛЬТАТЫ: анализ структуры задержки полового созревания у девочек в зависимости от картины заболевания показал, что I группу составили 39,2\% (20/51) пациенток, из которых 75\% (15/20) девочек с перманентной формой, 25\% (5/20) - с транзиторной формой задержки полового созревания (p=0,002).

Вторую группу составили 21,6\% (11/51) девочек. Структура задержки полового созревания у пациенток данной группы в большинстве случаев (81,8\% (9/11) была представлена перманентной формой и лишь в 18,2\% (2/11) транзиторной формой задержки полового созревания $(p=0,003)$.

Третью группу составили 39,2\% (20/51) девочек. В отличие от первых двух групп, перманентная форма диагностирована у 10\% (2/20) пациенток, транзиторная форма задержки полового созревания выявлена у 90\% (18/20) девочек (р<0,001).

Сравнение данных по группам показало, что по структуре задержки полового созревания (перманентная/транзиторная формы) I и II группы сопоставимы (р>0,05), в то время как III группа отличалась от двух других групп, преобладанием в своей структуре транзиторной формы задержки полового созревания $(p<0,001)$.

Выводы: установлена зависимость перманентной/транзиторной формы задержки полового созревания у девочек от клинической картины заболевания. В группах, где клиническая картина заболевания характеризовалась отсутствием вторичных половых признаков или их прогрессирования, в структуре преобладала перманентная форма задержки полового созревания, в то время как в случаях первичной аменореи - транзиторная форма. 